\title{
$18 \mathrm{Cr}-8 \mathrm{Ni}$ ステンレス鋼の孔食と応力腐食ワレに およ度すアニオンの影響*
}

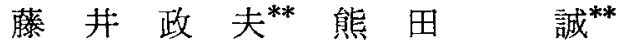

Masao Fujii and Makoto Kumada : Effects of Anions on Pitting Corrosion and Stress Corrosion Cracking in $18 \mathrm{Cr}-8 \mathrm{Ni}$ Stainless Steel. An experimental study has been carried out so as to investigate the effects of anions such as $\mathrm{CrO}_{4}{ }^{2-}, \mathrm{WO}_{4}{ }^{2-}, \mathrm{NO}_{3}{ }^{-}$and $\mathrm{H}_{2} \mathrm{PO}_{2}{ }^{-}$on pitting corrosion and stress corrosion cracking in $18 \mathrm{Cr}-8 \mathrm{Ni}$ stainless steel. The results obtained were summarized as follows :

(1) Efficiency of inhibition by anions against the dissolution of etch pits (active dissolution) decreases in the order : $\mathrm{CrO}_{4}{ }^{2-}, \mathrm{WO}_{4}{ }^{2-}, \mathrm{H}_{2} \mathrm{PO}_{2}{ }^{-} \gg \mathrm{NO}_{3}{ }^{-}$. The one by $\mathrm{NO}_{3}{ }^{-}$is not appreciable at all.

(2) Efficiency of inhibition by anions against the initiation of macro pits decreases in the order : $\mathrm{NO}_{3}{ }^{-} \geqq \mathrm{CrO}_{4}{ }^{2-}>\mathrm{WO}_{4}{ }^{2-}>\mathrm{H}_{2} \mathrm{PO}_{2}{ }^{-}$.

(3) Efficiency of inhibition by anions against growth of macro pits decreases in the order: $\mathrm{NO}_{3}{ }^{-}>\mathrm{WO}_{4}{ }^{2-}>\mathrm{CrO}_{4}{ }^{2-} \gg \mathrm{H}_{2} \mathrm{PO}_{2}{ }^{-}$.

(4) Efficiency of inhibition by anions against stress corrosion cracking decreases in order: $\mathrm{NO}_{3}^{-}>\mathrm{H}_{2} \mathrm{PO}_{2}^{-}>\mathrm{CrO}_{4}^{2-}, \mathrm{WO}_{4}^{2-}$.

(5) Marphology of pits and cracks in $18 \mathrm{Cr}-8 \mathrm{Ni}$ stainless steel in boiling $35 \% \mathrm{MgCl}_{2}$ solution containing various anions is unique to them. Cross-shaped pits, which are supposed to grow into cracks, initiate in the presence of $\mathrm{NO}_{3}{ }^{-}$. Only a few pits initiate in the presence of a large amount of $\mathrm{H}_{2} \mathrm{PO}_{2}{ }^{-}$, whereas fine cracks and a great number of pits initiate in the presence of a small amount of the anion. In the presence of $\mathrm{CrO}_{4}{ }^{2-}$ or $\mathrm{WO}_{4}{ }^{2-}$, pits are found on cracks.

(6) As the oxidizing abilitiy decreases in the order : $\mathrm{CrO}_{4}{ }^{2-}>\mathrm{NO}_{3}{ }^{-}>\mathrm{H}_{2} \mathrm{PO}_{2}{ }^{-}$, it seems that there is no relation between the oxidizing ability and the efficiency of inhibition against pits and cracks which are caused by $\mathrm{Cl}^{-}$ion.

(Recerved December 24, 1970)

** 三井造船株式会社玉野研究所 (Tamano Laboratory， Mistsui Ship Building \& Engineering Co., Ltd., Tamano)

* 1969 年 10 月第 16 回腐食防食討論会 (金沢) 飞発表

(1) 例えば, W.W.Kirk, F.H.Beck and M.G.Fontana: Physical Metallurgy of Stress Corrosion Fracture, Ed.by T.N.Rhodin, Interscience Publishers, New York, (1959)，227; 伊藤, 石原, 清水：金属学会誌, $30(1966), 888$.

\section{I. 緒言}

$\mathrm{Na}$ 塩を含を $50^{\circ} \mathrm{C}, 0.5 \mathrm{~N}-\mathrm{H}_{2} \mathrm{SO}_{4}$ 溶液中での $18 \mathrm{Cr}-8 \mathrm{Ni}$ 鋼の分極特性からフニオンとして $\mathrm{CrO}_{4}{ }^{2-}, \mathrm{WO}_{4}{ }^{2-}, \mathrm{NO}_{3}{ }^{-}$, $\mathrm{H}_{2} \mathrm{PO}_{2}$-を選び，乙れらのアニオンが孔食と応力腐食ワレ におよばす影響を調べた，孔食と応力腐食ワレとの関係に ついては従来多くの研究者達によって論じられてきた，高 温食塩水中でのワレが孔食を起点とする(1)ことは㴗注間違 
いない. また沸騰塩化マグネシウム溶液中でのワレもう りステップにおけける微小ピットを起点とする ${ }^{(2)}$ と考えられ る.したがって，孔食抑制に効果があるアニオンはワレ抑 制にも効果があることが推察される。このような観点に立 って，孔食と応力腐食ワレに怙よぼすアニオンの効果につ いて検討した結果を報告する.

\section{II. 実 験 方 法}

\section{1. 孔食実験}

試料は $0.3 \mathrm{~mm}$ 厚 SUS 27 をエメリー紙 05 まで研摩後, 真空中で $1050^{\circ} \mathrm{C} \times 30 \mathrm{~min}$ 焼鈍し急冷して, さらに $\mathrm{H}_{3} \mathrm{PO}_{4}$ $\mathrm{H}_{2} \mathrm{SO}_{4}$ 溶液㧍よび $\mathrm{H}_{3} \mathrm{PO}_{4}-\mathrm{H}_{2} \mathrm{SO}_{4}-\mathrm{CrO}_{3}$ 溶液中で二段電解研 摩したものである。この実験では，方位性ピット(含酸素 $1 \mathrm{~N}-\mathrm{H}_{2} \mathrm{SO}_{4}+100 \mathrm{mg} / \mathrm{L} \mathrm{NH}_{4} \mathrm{SCN}$ 溶液中 $-0.2 \mathrm{~V}$ vs SCE 保 持) とマクロ・ピット(含酸素 $1 \mathrm{~N}-\mathrm{H}_{2} \mathrm{SO}_{4}+\mathrm{NaCl}$ 溶液中 $+0.4 \mathrm{~V}$ vs SCE 保持) の発生, 成長に対するアニオン $\left(\mathrm{CrO}_{4}{ }^{2-}, \mathrm{WO}_{4}{ }^{2-}, \mathrm{NO}_{3}{ }^{-}, \mathrm{H}_{2} \mathrm{PO}_{2}{ }^{-}\right)$の抑制効果を調べた。

\section{2. 応力腐食ワレ実験}

試料は巾 $10 \mathrm{~mm} \times$ 長さ $75 \mathrm{~mm} \times$ 厚み $2 \mathrm{~mm}$ の SUS 27 を $1050^{\circ} \mathrm{C} \times 30 \mathrm{~min}$ 焼鈍し急冷して, エメリー紙 04 まで 研摩後 $\mathrm{H}_{3} \mathrm{PO}_{4}-\mathrm{H}_{2} \mathrm{SO}_{4}$ 溶液中で電解研摩したものである. 応力は 3 点支持ビーム治具によって, $30 \mathrm{~kg} / \mathrm{mm}^{2}$ を付加し た. 沸騰 $35 \% \mathrm{MgCl}_{2}$ 溶液 (特級 $\mathrm{MgCl}_{2} \cdot 6 \mathrm{H}_{2} \mathrm{O}$ 使用, 常温 で $\mathrm{pH}=4$ ～ 5 ) 中でワレ感受性に対する前記アニオンの効果 を調べた

\section{III. 実験結果および考察}

\section{1. 孔食実験}

\section{（1） $\mathrm{Na}$ 塩を含む $50^{\circ} \mathrm{C}, 0.5 \mathrm{~N}-\mathrm{H}_{2} \mathrm{SO}_{4}$ 溶液中での} $18 \mathrm{Cr}-8 \mathrm{Ni}$ 鋼の分極特性

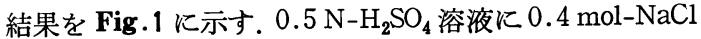

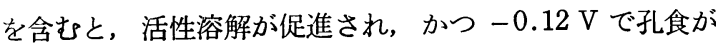
発生する.この $0.5 \mathrm{~N}-\mathrm{H}_{2} \mathrm{SO}_{4}+0.4 \mathrm{~mol}-\mathrm{NaCl}$ 溶液にアニ オンが共存すると, $\mathrm{CrO}_{4}{ }^{2-}, \mathrm{WO}_{4}{ }^{2-}, \mathrm{H}_{2} \mathrm{PO}_{2}-$ は活性溶解を 完全に抑制するが, $\mathrm{NO}_{3}^{-}$はその効果がない. したがって, $\mathrm{CrO}_{4}{ }^{2-}, \mathrm{WO}_{4}{ }^{2-}, \mathrm{H}_{2} \mathrm{PO}_{2}^{-}$は $\mathrm{SCN}^{-}$による方位性ピット溶解 を抑制することが予想される. 一方, $\mathrm{Cl}^{-}$によるマクロ・ピ ット溶解を $\mathrm{CrO}_{4}{ }^{2-}, \mathrm{NO}_{3}{ }^{-}$は抑制するが, $\mathrm{WO}_{4}{ }^{2-}$ はその効 果が弱く，また $\mathrm{H}_{2} \mathrm{PO}_{2}$ - はその効果がないと考えられる.

(2) アニオンの方位性ピット溶解抑制効果

Fig.2 にアニオンのピット成長抑制効果を示す. $1 \mathrm{~N}-$ $\mathrm{H}_{2} \mathrm{SO}_{4}$ 溶液中 $-0.2 \mathrm{~V}, 30 \mathrm{~min}$ 保持後 $\mathrm{NH}_{4} \mathrm{SCN}$ を含む $1 \mathrm{~N}$ $\mathrm{H}_{2} \mathrm{SO}_{4}$ 溶液を加え, $1 \mathrm{~N}-\mathrm{H}_{2} \mathrm{SO}_{4}+100 \mathrm{mg} / \mathrm{L} \mathrm{NH}_{4} \mathrm{SCN}$ 溶液中

（2）例えば, H.W. Pickering and P.R.Swann : 2nd International Congress on Metallic Corrosion, NACE, Houston, (1966), 128; D. Tromans and J.Nutting: Corrosion, 21 (1965) , 143 : T. J. Smith and R. W. Staehle : Corrosion, 23 (1967), 117.

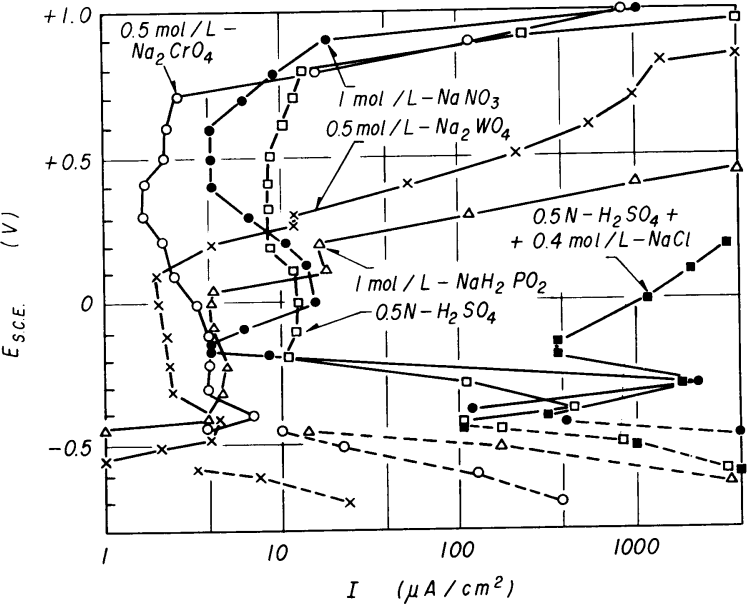

Fig. 1 Polarization curves of $18 \mathrm{Cr}-8 \mathrm{Ni}$ steel in $0.5 \mathrm{~N}-$ $\mathrm{H}_{2} \mathrm{SO}_{4}+0.4 \mathrm{~mol} / \mathrm{L}-\mathrm{NaCl}+\mathrm{NaX}$ solution at $50^{\circ} \mathrm{C}$

で方位性ピットを発生させ，さらにて（電流-時間曲線にお いて電流が立上る時間) 後 $10 \mathrm{~min}$ に, 全量に対して $1 \mathrm{~mol}$ になるように各種アニオンを添加した. 1. (1) 項で予想し たように, $\mathrm{CrO}_{4}{ }^{2-}, \mathrm{WO}_{4}{ }^{2-}, \mathrm{H}_{2} \mathrm{PO}_{2}-$ は方位性ピット溶解を 抑制するが, $\mathrm{NO}_{3}$ - は全然その効果がない. $\mathrm{CrO}_{4}{ }^{2-}$ の効果 は $\mathrm{NH}_{4} \mathrm{SCN}$ の量を $100 \mathrm{mg} / \mathrm{L}$ から $1 \mathrm{~g} / \mathrm{L}$ に変え, $\mathrm{SCN}^{-}$量 を 10 倍にしても如実にあらわれる. 一方, $\mathrm{NO}_{3}{ }^{-}$の効果は その量を 5 倍にしても認められない(Fig.3).

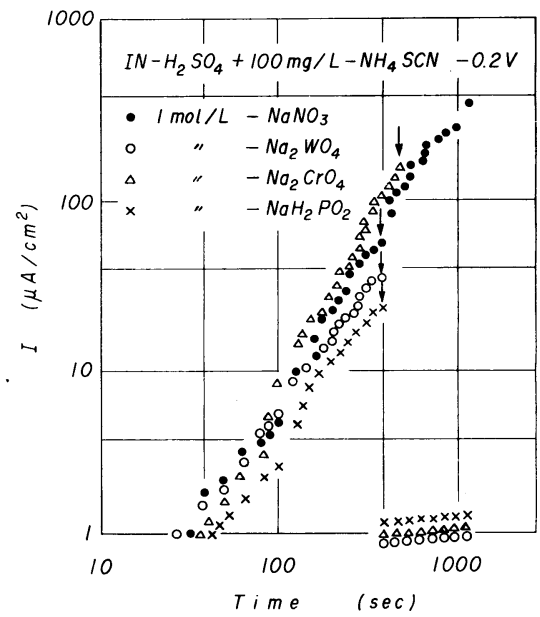

Fig.2 Effect of various anions on inhibition of dissolution of etch-pits in $18 \mathrm{Cr}-8 \mathrm{Ni}$ steel. All sodium compounds were added at the time shown with arrow mark $\downarrow$

(3) アニオンのマクロ・ピット溶解抑制効果

Fig.4 にアニオンのピット成長抑制効果を示す. $1 \mathrm{~N}$ $\mathrm{H}_{2} \mathrm{SO}_{4}$ 溶液中 $+0.4 \mathrm{~V}, 30 \mathrm{~min}$ 保持後 $\mathrm{NaCl}$ を含む $1 \mathrm{~N}$ $\mathrm{H}_{2} \mathrm{SO}_{4}$ 溶液を加え, $1 \mathrm{~N}-\mathrm{H}_{2} \mathrm{SO}_{4}+1 \mathrm{~mol}-\mathrm{NaCl}$ 溶液中でマク ロ・ピットを発生させ,ささらに $\tau$ 後 $6 \sim 10 \mathrm{~min}$ 全量に対し て $1 \mathrm{~mol}$ になるように各種アニオンを添加した. $\mathrm{NO}_{3}{ }^{-}$は ピット溶解を完全に抑制する. しかし $\mathrm{CrO}_{4}{ }^{2-}$ と $\mathrm{WO}_{4}{ }^{2-}$ の 


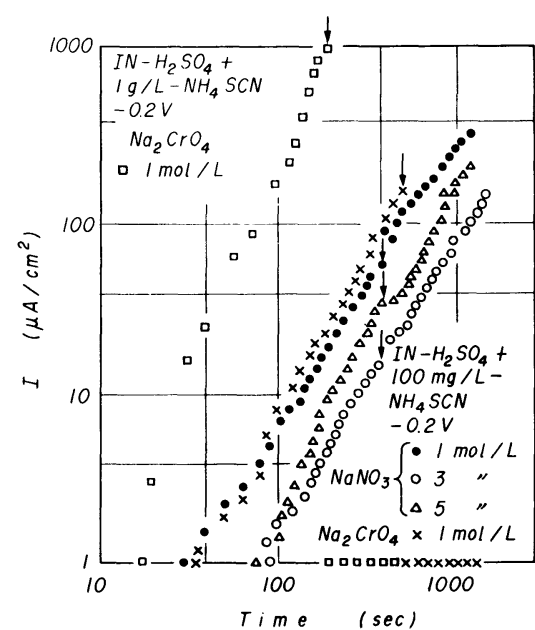

Fig.3 Effect of $\mathrm{NaNO}_{3}$ and $\mathrm{Na}_{2} \mathrm{CrO}_{4}$ on inhibition of dissolution of etch-pits in $18 \mathrm{Cr}-8 \mathrm{Ni}$ steel. Both sodium compounds were added at the time shown with arrow mark $\downarrow$

効果は Fig.1から得られた知見とは全く逆で, $\mathrm{CrO}_{4}{ }^{2-}$ はピ ット溶解抑制効果は弱いが， $\mathrm{WO}_{4}{ }^{2-}$ は $\mathrm{NO}_{3}$ - 同様抑制効果 が強い. $\mathrm{H}_{2} \mathrm{PO}_{2}$ - の添加によって一時溶解が抑制されるが, 再び電流が著しく増大するので, $\mathrm{H}_{2} \mathrm{PO}_{2}$-にはマクロ・ピッ 卜溶解抑制効果がないと考学られる。

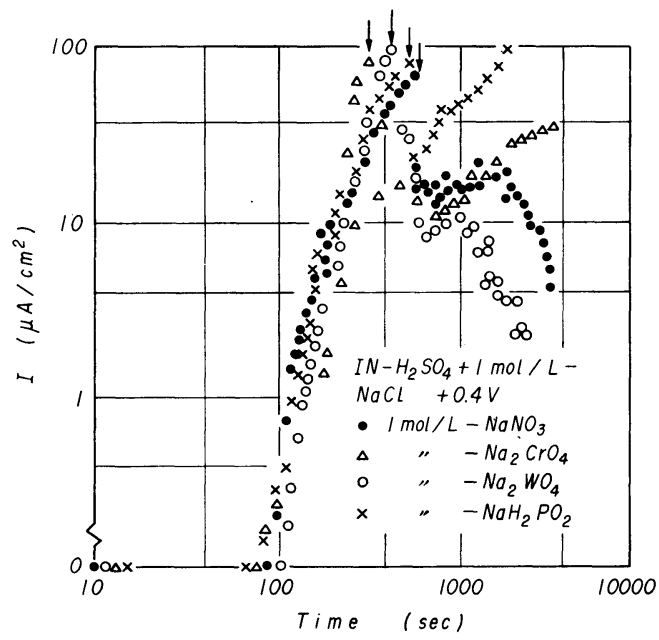

Fig.4 Effect of various anions on inhibition of dissolution of macro pits in $18 \mathrm{Cr}-8 \mathrm{Ni}$ steel. All sodium compounds were added at the time shown with arrow mark $\downarrow$

さらに $\mathrm{NO}_{3}$ - の効果を詳しく調べるため, $1 \mathrm{~N}-\mathrm{H}_{2} \mathrm{SO}_{4}+$ $1 \mathrm{~mol}-\mathrm{NaCl}+\mathrm{NaNO}_{3}$ 溶液中 $+0.4 \mathrm{~V}$ で $i-t$ (電流-時間) 曲

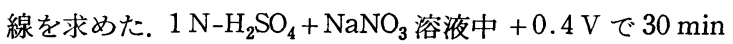
保持後 $\mathrm{NaCl}$ を加えた. その結果を Fig.5 亿示す. $i \approx 10 \mu$ $\mathrm{A} / \mathrm{cm}^{2}$ を不働態推持電流と考えると, $1 \mathrm{~mol}-\mathrm{NaCl}$ に対し て $\mathrm{NO}_{3} \approx 0.5 \mathrm{~mol}$ がピット溶解抑制の限界量となる. Leckie and Uhlig ${ }^{(3)}$ の式 $\log \left(\mathrm{Cl}^{-}\right)=1.88 \log \left(\mathrm{NO}_{3}^{-}\right)+1.88^{\dagger}$ によって求めた $\mathrm{NO}_{3}^{-}$量は $0.32 \mathrm{~mol}$ である.

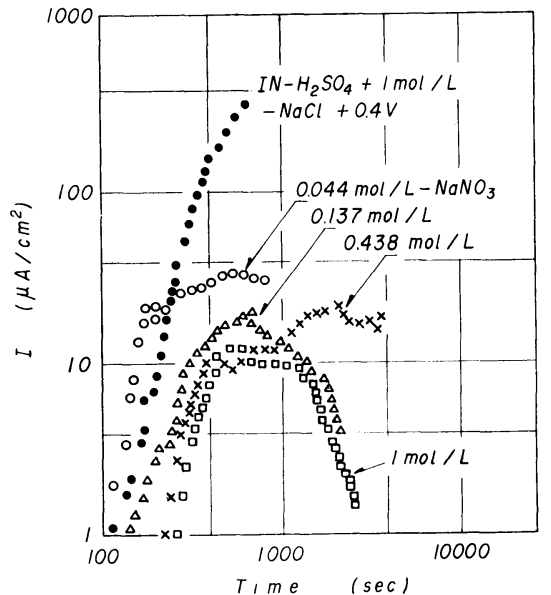

Fig.5 Effect of $\mathrm{NaNO}_{3}$ on $i$ - $t$ curves of $18 \mathrm{Cr}$ $8 \mathrm{Ni}$ steel in $1 \mathrm{~N}-\mathrm{H}_{2} \mathrm{SO}_{4}+1 \mathrm{~mol} / \mathrm{L}-\mathrm{NaCl}$ solution

つぎに $\mathrm{NO}_{3}$-の効果を確かめるため, $50^{\circ} \mathrm{C}, \mathrm{N} / 20-\mathrm{HCl}+$ $10 \% \mathrm{FeCl}_{3}$ 溶液中に打ける孔食防止に必要な $\mathrm{NO}_{3}$ - 量を求 めた. この $\mathrm{NO}_{3}^{-}$量は $5 \mathrm{~mol}$ で, Photo.1 に示されるよう に, 皮膜のワレ目で生ずる優先腐食 ${ }^{(4)}$ はほぼ完全に防止さ れる.

\section{2. 応力腐食ワレ実験}

\section{（1）ワレ感受性とアニオンとの関係}

結果をFig.6 に示す. 各種アニオンを Na 塩の形で加え たので, $\mathrm{Na}$ 塩の量とワレ発生時間との関係で整理した。 各直線の下側では $\sigma=30 \mathrm{~kg} / \mathrm{mm}^{2}$ でワレが発生し, 上側で はワレは発生しない. ワレ防止に必要なアニオンの量は, $\mathrm{NO}_{3}{ }^{-}<\mathrm{H}_{2} \mathrm{PO}_{2}{ }^{-}<\mathrm{CrO}_{4}{ }^{2-}, \mathrm{WO}_{4}{ }^{2-}$ となり, $\mathrm{CrO}_{4}{ }^{2-}$ では $\mathrm{NO}_{3}{ }^{-}$ の 5 倍以上, $\mathrm{WO}_{4}{ }^{2-}$ では 7 倍以上要する. $\mathrm{H}_{2} \mathrm{PO}_{2}{ }^{-}$は還元 性イオンであるにもかかわらず, $\mathrm{NO}_{3}{ }^{-}$と $\mathrm{CrO}_{4}{ }^{2-}, \mathrm{WO}_{4}{ }^{2-}$ との中間の挙動を示した. ピットおよびワレ形態におよぼ すアニオンの影響の代表例をPhoto.2 6亿示す. $\mathrm{NO}_{3}$ をを 含む場合には，大谷，藤島 ${ }^{(5)}$ にっって $\mathrm{Al}-\mathrm{Cu}$ 合金に認め られた十字形ピットを生じ (Photo.3(a)), ワレもこの十 字形のピットと関係がある(Photo.3(b)) と考えられる. $\mathrm{H}_{2} \mathrm{PO}_{2}$-を含む場合, Fig.6 の直線より上側では $\mathrm{H}_{2} \mathrm{PO}_{2}$-が 多量のときはワレ発生がなく、ピットは極く僅かしか認め られなかった(Photo.4(a))。直線より下側では微細なワレ と無数のピットが共存する(Photo. 4 (b)). $\mathrm{CrO}_{4}{ }^{2-}$ と $\mathrm{WO}_{4}{ }^{2-}$ を含む場合には，ワレ目上にピットが認められた (Photo.5 および6)が，このワレ目がピットを起点としたのか，ワ レ目での吵間腐食によってピットが発生したのか明確でな い. $\mathrm{CrO}_{4}{ }^{2-}$ 存在下では, 大きなピットのほかに治具との接 触部に隙間腐食を生じた。

(3) H.P.Leckie and H.H.Uhlig : J.Electrochem.Soc., $113(1966), 1262$.

（4）藤井, 熊田 : 金属学会誌, 34(1970), 1005.

（5）大谷, 藤島 : 金属学会誌, 33 (1969)，599.

$\dagger$ ( ) は活量. 


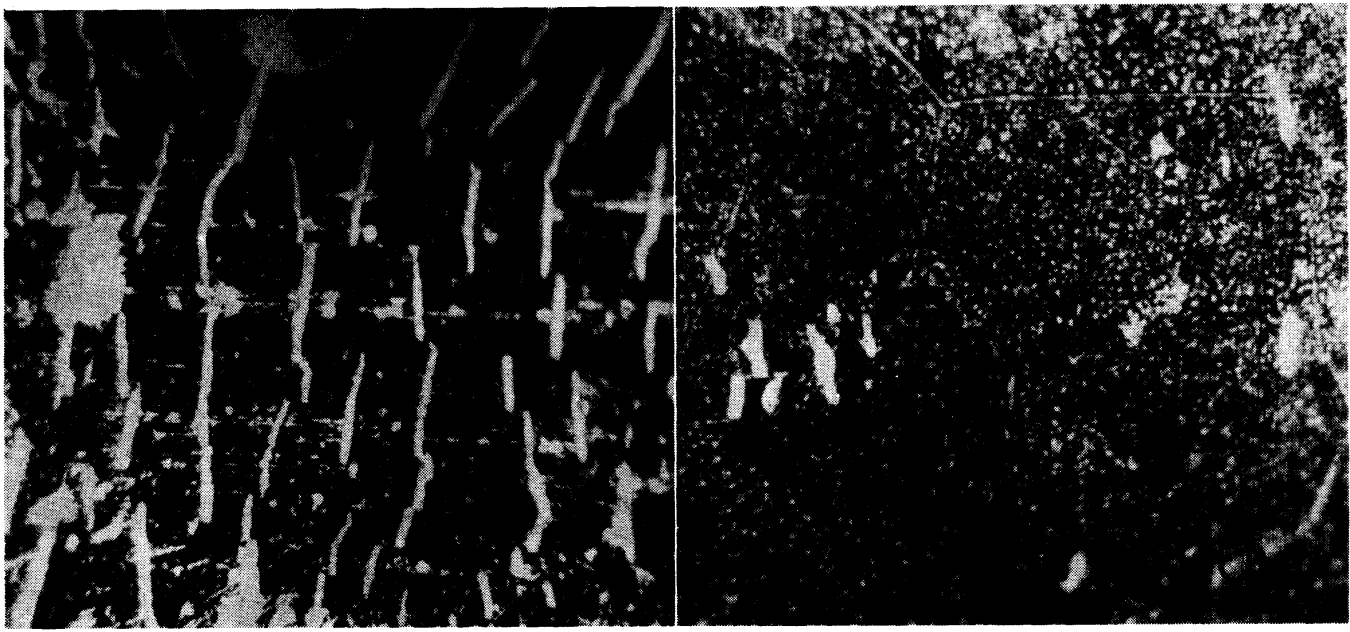

Photo.1 Microstructure of preferential attacks which occurred on cracks of oxide film formed by plastic deformation at the bend surface-flat surface boundary. Electropolishing $\rightarrow 1.5 \mathrm{hr}$ oxidizing at $580^{\circ} \mathrm{C}$ in air $\rightarrow 105^{\circ}$ bend $\rightarrow$ Exposure for $1 \mathrm{~min}$ in (a) $\mathrm{N} / 20-\mathrm{HCl}+10 \% \mathrm{FeCl}_{3}$ and (b) $\mathrm{N} / 20-\mathrm{HCl}+10 \% \mathrm{FeCl}_{3}+5 \mathrm{~mol} / \mathrm{L} \mathrm{NaNO}_{3}$ solution at $50^{\circ} \mathrm{C}$

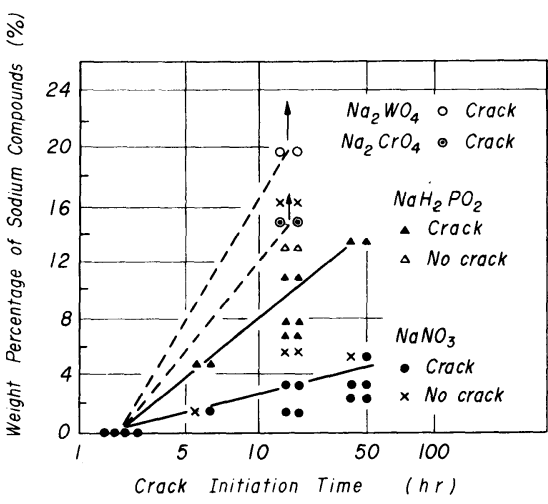

Fig.6 Relation between stress corrosion cracking sensibility of $18 \mathrm{Cr}-8 \mathrm{Ni}$ steel and anions in boiling $35 \% \mathrm{MgCl}_{2}$ solution

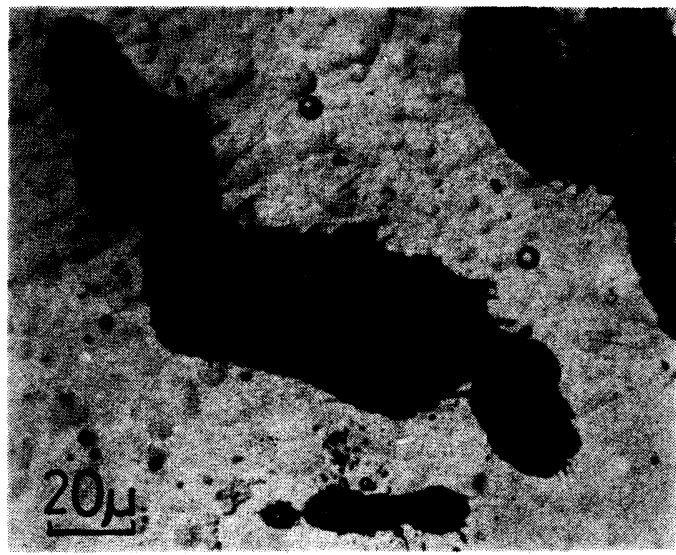

Photo. 2 Stress corrosion cracking of $18 \mathrm{Cr}-8 \mathrm{Ni}$ stainless steel under a stress of $30 \mathrm{~kg} /$ $\mathrm{mm}^{2}$ and tested for $18 \mathrm{hr}$ in boiling $35 \% \mathrm{MgCl}_{2}$ solution
（2）分極特性

各種アニオンを含む沸騰 $35 \% \mathrm{MgCl}_{2}$ 溶液中での腐食挙 動を明確にする目的で, $18 \mathrm{Cr}-8 \mathrm{Ni}$ 鋼の腐食電位と溶液の Redox 電位を測定した. 結果を Table 1 に示す. 18 Cr-8 $\mathrm{Ni}$ 鋼は無応力の状態である.腐食電位はアニオンが含まれ ても沸騰 $35 \% \mathrm{MgCl}_{2}$ 溶液のみの場合とほとんど変わらず, $-0.4 \sim-0.25 \mathrm{~V}$ の応力腐食ワレが起こり易い電位域にあ る. アニオンは $18 \mathrm{Cr}-8 \mathrm{Ni}$ 鋼の腐食電位を変えない.

つぎに板状 Pt を用いて溶液の還元特性を調べた.その 結果を Fig.7 亿示す. 酸化力は $\mathrm{CrO}_{4}{ }^{2-}>\mathrm{NO}_{3}{ }^{-}>\mathrm{H}_{2} \mathrm{PO}_{2}{ }^{-}$で ある。

\section{3. アニオンの効果}

以上の結果からアニオンの効果ををとめると Table 2 の ようになる.

森岡ら ${ }^{(6)}$ は, $18 \mathrm{Cr}-8 \mathrm{Ni}$ ステンレス鋼は硫酸酸性水溶液 中で活性溶解するが，亜硫酸酸性水溶液中ではその酸化力 によって自発不働態化することを示した. しかし本実験結 果によれば，方位性ピット(換言すれば活性溶解)の抑制効 果は必ずしも酸化力に依存するものではない.

一方, マクロ・ピット発生, 成長およびワレの抑制効果 も酸化力と関係がない：このようなピットおよびワレの抑 制には $\mathrm{NO}_{3}^{-}$が最も効果があるが，他のアニオンの効果は 全くランダムである. アニオンの効果がアニオンの如何 なる性質によるのか本実験の範囲では明らかでないが， Leckie and Uhlig ${ }^{(3)}$ は吸着効果と考学ている. Uhlig and Gilman ${ }^{(7)}$ や森岡ら ${ }^{(6)}$ にれば, $\mathrm{NO}_{3}{ }^{-}$によるマクロ・ピット の抑制効果はアノード面への吸着である. このように考光 ると, 応力腐食の場合 $-0.4 \sim-0.25 \mathrm{~V}$ の活性領域 ${ }^{(8)}$ で,

（6）森岡，沢田，塩原：防蝕技術，14(1965)，535.

(7) H.H.Uhlig aod J.R.Gilman : Corrosion, 20 (1964), 289. 


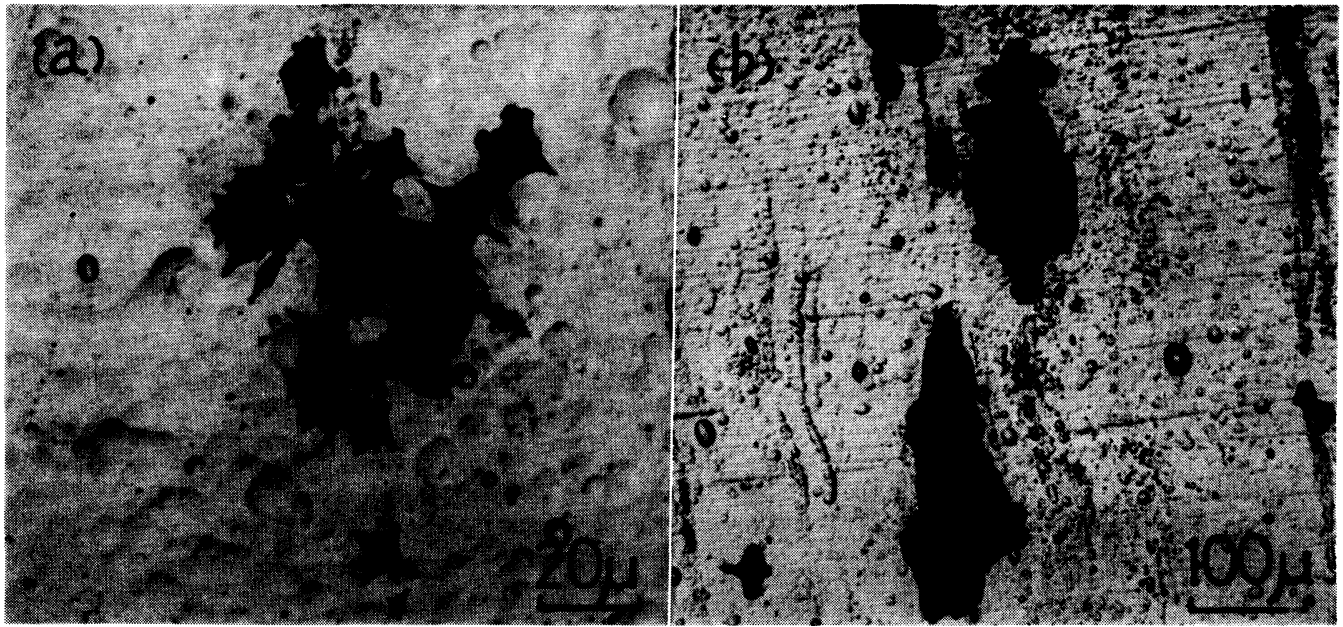

Photo.3 Microstructure of pits and cracks of $18 \mathrm{Cr}-8 \mathrm{Ni}$ stainless steel in boiling $35 \% \mathrm{MgCl}_{2}$ solution containing $\mathrm{NO}_{3}^{-}$ion

(a) $\sigma=30 \mathrm{~kg} / \mathrm{mm}^{2}, 35 \% \mathrm{MgCl}_{2}+33.6 \% \mathrm{NaNO}_{3}, 20 \mathrm{hr}$

(b) $\sigma=30 \mathrm{~kg} / \mathrm{mm}^{2}, 35 \% \mathrm{MgCl}_{2}+4 \% \mathrm{NaNO}_{3}, 48 \mathrm{hr}$

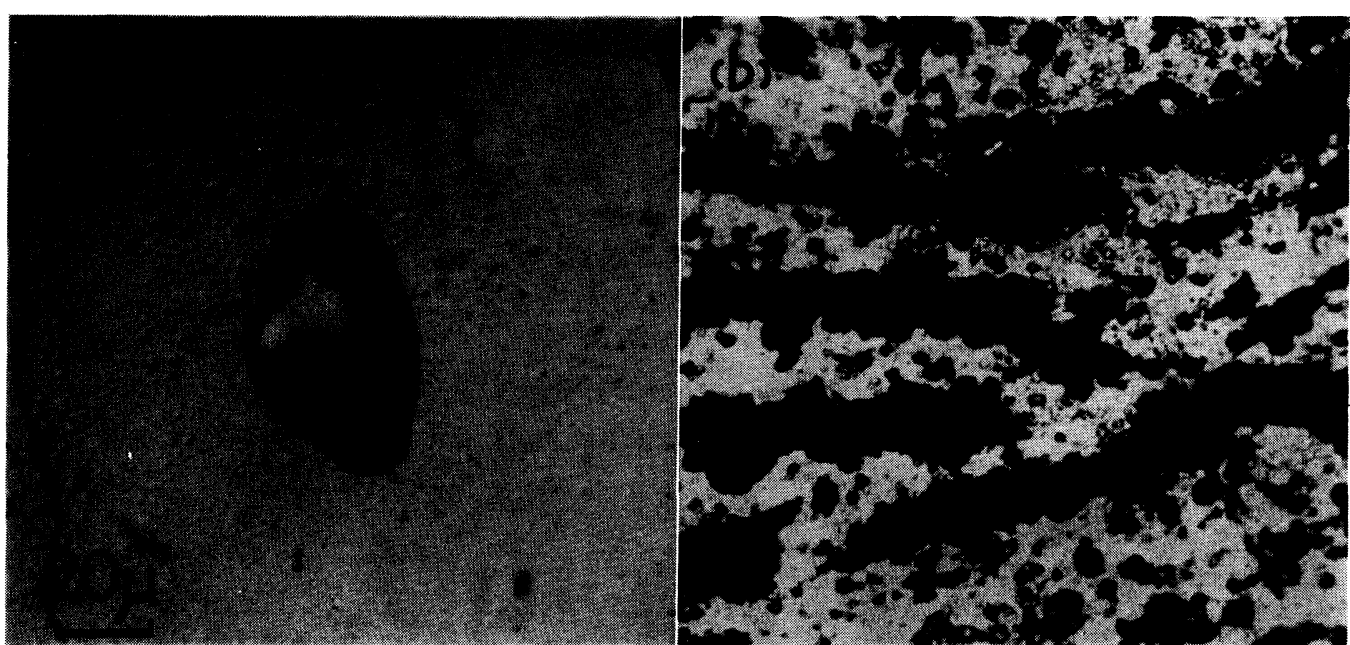

Photo. 4 Microstructure of pits and cracks of $18 \mathrm{Cr}-8 \mathrm{Ni}$ stainless steel in boiling $35 \% \mathrm{MgCl}_{2}$ solution containing $\mathrm{H}_{2} \mathrm{PO}_{2}^{-}$ion

(a) $\sigma=30 \mathrm{~kg} / \mathrm{mm}^{2}, 35 \% \mathrm{MgCl}_{2}+20 \% \mathrm{NaH}_{2} \mathrm{PO}_{2}, 20 \mathrm{hr}$

(b) $\sigma=30 \mathrm{~kg} / \mathrm{mm}^{2}, 35 \% \mathrm{MgCl}_{2}+5.3 \% \mathrm{NaH}_{2} \mathrm{PO}_{2}, 20 \mathrm{hr}$

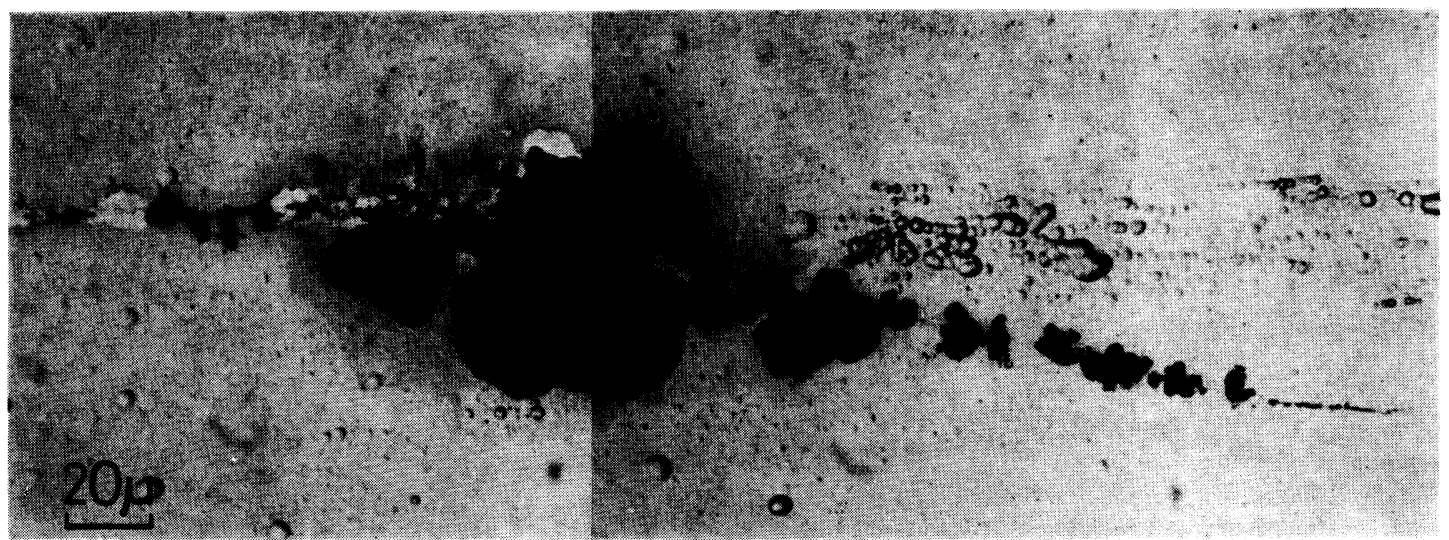

Photo.5 Microstructure of pits and cracks of $18 \mathrm{Cr}-8 \mathrm{Ni}$ stainless steel under a stress of $30 \mathrm{~kg} / \mathrm{mm}^{2}$ and tested for $20 \mathrm{hr}$ in boiling $35 \% \mathrm{MgCl}_{2}$ solution containing $15 \% \mathrm{Na}_{2} \mathrm{CrO}_{4}$ 


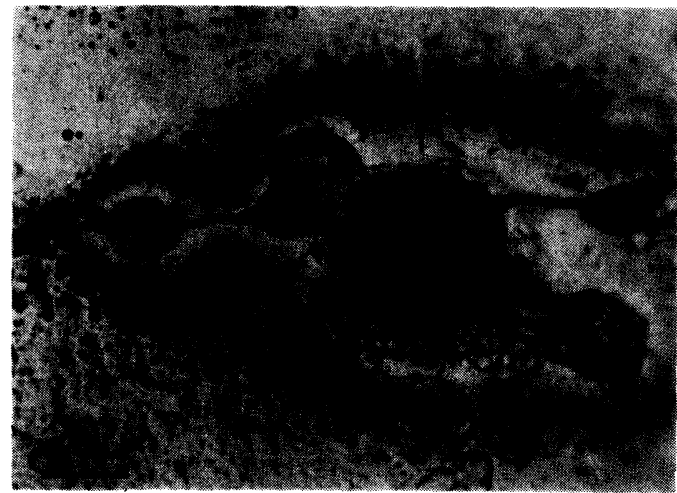

Photo.6 Microstructure of pits and cracks of $18 \mathrm{Cr}$ $8 \mathrm{Ni}$ stainless steel under a stress of $30 \mathrm{~kg} /$ $\mathrm{mm}^{2}$ and tested for $20 \mathrm{hr}$ in boiling 35\% $\mathrm{MgCl}_{2}$ solution containing $20 \% \mathrm{Na}_{2} \mathrm{WO}_{4}$

Table 1 Redox potential of boiling $35 \% \mathrm{MgCl}_{2}$ solution containing various anions and corrosion potential of $18 \mathrm{Cr}-8 \mathrm{Ni}$ steel

\begin{tabular}{|c|c|c|}
\hline Solution & Redox potential & $\begin{array}{l}\text { Corrosion potential } \\
\text { of } 18 \mathrm{Cr}-8 \mathrm{Ni} \text { steel } \\
\text { at } 3 \mathrm{hr} \text { after ex- } \\
\text { posure }(\mathrm{V})\end{array}$ \\
\hline Boiling $35 \% \mathrm{MgCl}_{2}$ & -0.12 & -0.40 \\
\hline $\begin{array}{l}\text { Boiling } 35 \% \mathrm{MgCl}_{2} \\
+1 \mathrm{~mol} / \mathrm{L} \mathrm{NaNO}_{3}\end{array}$ & +0.37 & -0.34 \\
\hline $\begin{array}{l}\text { Boiling } 35 \% \mathrm{MgCl}_{2} \\
+0.25 \mathrm{~mol} / \mathrm{L} \mathrm{NaNO}_{3}\end{array}$ & +0.40 & -0.37 \\
\hline $\begin{array}{l}\text { Boiling } 35 \% \mathrm{MgCl}_{2} \\
+1 \mathrm{~mol} / \mathrm{L} \mathrm{NaH}_{2} \mathrm{PO}_{2}\end{array}$ & -0.39 & -0.35 \\
\hline $\begin{array}{l}\text { Boiling } 35 \% \mathrm{MgCl}_{2} \\
+3 \mathrm{~mol} / \mathrm{L} \mathrm{NaH} \mathrm{PO}_{2}\end{array}$ & -0.43 & -0.45 \\
\hline $\begin{array}{l}\text { Boiling } 35 \% \mathrm{MgCl}_{2} \\
+1 \mathrm{~mol} / \mathrm{L} \mathrm{Na} \mathrm{CrO}_{4}\end{array}$ & +0.64 & -0.26 \\
\hline
\end{tabular}

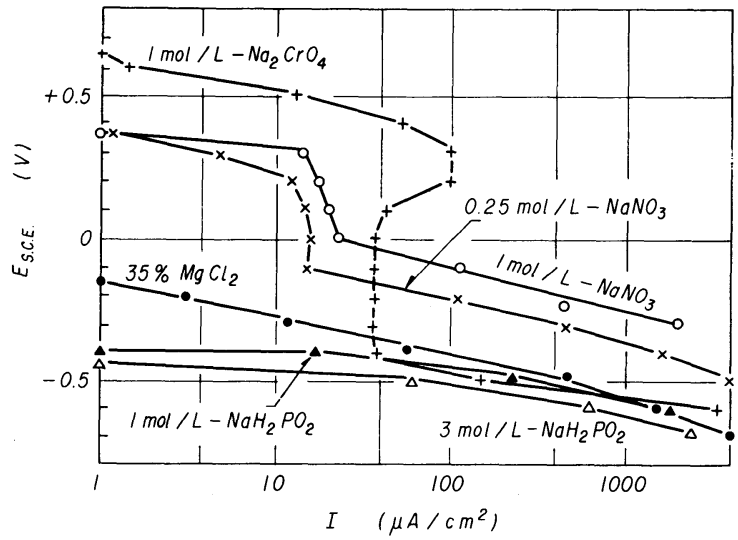

Fig.7 Cathodic polarization curves of $\mathrm{Pt}$ in boiling 35\% $\mathrm{MgCl}_{2}$ solution containing various anions

(8) 石川：第 3 回コロージョン・セミナテキスト, 学振 第 97 委員会編, $(1969), 45$.
Table 2 Efficiency of inhibition by various anions

\begin{tabular}{|c|c|}
\hline Inhibition & Efficiency of inhibition \\
\hline $\begin{array}{l}\text { Inhibition of dissolution of } \\
\text { etch-pits (Fig. } 2 \text { ) = Inhibition } \\
\text { of active dissolution }\end{array}$ & $\begin{array}{l}\mathrm{CrO}_{4}{ }^{2-}, \mathrm{WO}_{4}{ }^{2-}, \mathrm{H}_{2} \mathrm{PO}_{2}^{-} \gg \\
\mathrm{NO}_{3}^{-}\end{array}$ \\
\hline $\begin{array}{l}\text { Inhibition of initiation of } \\
\text { macro pits (Fig. } 1 \text { ) }\end{array}$ & $\begin{array}{l}\mathrm{NO}_{3}{ }^{-} \geqq \mathrm{CrO}_{4}{ }^{2-}>\mathrm{WO}_{4}{ }^{2-}> \\
\mathrm{H}_{2} \mathrm{PO}_{2-}^{--}\end{array}$ \\
\hline $\begin{array}{l}\text { Inhibition of growth of } \\
\text { macro pits (Fig.4) }\end{array}$ & $\begin{array}{l}\mathrm{NO}_{3}{ }^{-}>\mathrm{WO}_{4}{ }^{2-}>\mathrm{CrO}_{4}{ }^{2-} \gg \\
\mathrm{H}_{2} \mathrm{PO}_{2}-\end{array}$ \\
\hline $\begin{array}{l}\text { Inhibition of stress corrosion } \\
\text { cracking (Fig.6) }\end{array}$ & $\underset{\mathrm{WO}_{4}^{2-}}{\mathrm{NO}_{3}-}>\mathrm{H}_{2} \mathrm{PO}_{2}->\mathrm{CrO}_{4}^{2-}$, \\
\hline Oxidizing ability (Fig.7) & $\mathrm{CrO}_{4}{ }^{2-}>\mathrm{NO}_{3}{ }^{-}>\mathrm{H}_{2} \mathrm{PO}_{2}{ }^{-}$ \\
\hline
\end{tabular}

亡りステップ先端のアクティブ・フロントで起こる溶解の 抑制に, $\mathrm{NO}_{3}$ - が効果がある理由は吸着によって説明され るよらに思われるが, 実際はそう簡単ではない. Schwenk ${ }^{(9)}$ によれば硝酸塩インヒビターの効果は高電位領域に限定さ れる. 事実, Fig.2, Fig.4によれば, $\mathrm{NO}_{3}^{-}$は低電位で生 ずるピットの抑制に効果がないが，高電位で生ずるピット の抑制に効果がある。したがって, 活性溶解の抑制に効果 がない $\mathrm{NO}_{3}{ }^{-}$が何故, 立りステップ先端のアクティブ・フ ロントで起こる溶解の抑制に効果があるのか, また, マク ロ・ピット内の電位が $-0.25 \mathrm{~V}$ の活性域 ${ }^{(10)}$ にあるもか かわらず, 活性溶解の抑制に効果があるアニオン $\left(\mathrm{CrO}_{4}{ }^{2-}\right.$, $\left.\mathrm{H}_{2} \mathrm{PO}_{2}^{-}\right)$が何故, マクロ・ピットの成長抑制に効果がない のか疑問である.このような現象を理解するには，従来の データだけでは不十分で, 分極中の $18 \mathrm{Cr}-8 \mathrm{Ni}$ 鋼の界面イ ンピーダンス(11)を測定して，界面現象にアニオンがどの ように影響するかを知る必要があると思われる。また大谷 $ら^{(12)}$ が映画による $18 \mathrm{Cr}-8 \mathrm{Ni}$ ステンレス鋼の方位性ピッ トの観察からピット成長の律速過程を決定した手法を用い て,アニオンを含む場合のピットの成長過程における見掛 けの活性化エネルギーを求め, ピット成長の律速過程にお よぼすアニオンの効果を知るのも一方法と思われる。

\section{IV. 総 括}

$\mathrm{Na}$ 塩を含む $50^{\circ} \mathrm{C}, 0.5 \mathrm{~N}-\mathrm{H}_{2} \mathrm{SO}_{4}$ 溶液中での $18 \mathrm{Cr}-8 \mathrm{Ni}$ 鋼の分極特性からアニオンとして $\mathrm{CrO}_{4}{ }^{2-}, \mathrm{WO}_{4}{ }^{2-}, \mathrm{NO}_{3}{ }^{-}$, $\mathrm{H}_{2} \mathrm{PO}_{2}$ - を選び，これらのアニオンが孔食と応力腐食ワレ におよぼす影響について調べた，得られた結果はつぎのよ らにまとめられる.

(1) 方位性ピット溶解 (活性溶解) の抑制効果は $\mathrm{CrO}_{4}{ }^{2-}$, $\mathrm{WO}_{4}{ }^{2-}, \mathrm{H}_{2} \mathrm{PO}_{2}{ }^{-} \gg \mathrm{NO}_{3}{ }^{-}$で, $\mathrm{NO}_{3}{ }^{-}$はその効果が全然ない.

(9) W.Schwenk : Corrosion, 20 (1964), 129

（10）鈴木，北村：防蝕技術，18(1969)，100.

（11）例之ば，杉本，沢田：第 16 回腐食防食討論会講演 要旨集, (1969), 79.

(12) 大谷, 相原, 高本：金属学会誌, 33 (1969)，432。 
（2）マクロ・ピット発生の抑制効果は $\mathrm{NO}_{3}{ }^{-} \geqq \mathrm{CrO}_{4}{ }^{2-}>\quad$ 合には，その量が多いときは極く僅かのピットだけが発生 $\mathrm{WO}_{4}{ }^{2-}>\mathrm{H}_{2} \mathrm{PO}_{2}{ }^{-}$である.

(3) マク口・ピット成舆の抑制站果は $\mathrm{NO}_{3}{ }^{-}>\mathrm{WO}_{4}{ }^{2-}>$ $\mathrm{CrO}_{4}{ }^{2-} \gg \mathrm{H}_{2} \mathrm{PO}_{2}{ }^{-}$で, $\mathrm{CrO}_{4}{ }^{2-}$ は効果が弱く, $\mathrm{H}_{2} \mathrm{PO}_{2}{ }^{-}$は効果 がない.

(4) 位力腐食ワレの抑制效果は $\mathrm{NO}_{3}^{-}>\mathrm{H}_{2} \mathrm{PO}_{2}^{-}>\mathrm{CrO}_{4}{ }^{2-}$, $\mathrm{WO}_{4}{ }^{2-}$ で, $\mathrm{H}_{2} \mathrm{PO}_{2}^{-}$は還元性イオンであるにもかかからず, $\mathrm{NO}_{3}{ }^{-}\left\llcorner\mathrm{CrO}_{4}{ }^{2-}, \mathrm{WO}_{4}{ }^{2-}\right.$ との中間の挙動を示した。

(5) 各種アニオンを含む沸騰 $35 \% \mathrm{MgCl}_{2}$ 溶液中に打惊 る $18 \mathrm{Cr}-8 \mathrm{Ni}$ 鋼のピットおよびワレの形態は, アニオン に特有なものである． $\mathrm{NO}_{3}^{-}$を含む場合にはワレに成長す ると考えられる十字形ピットを生じる. $\mathrm{H}_{2} \mathrm{PO}_{2}^{-}$を含も場 し，一方少ないとさは微細なワレと無数のピットが発生す る. $\mathrm{CrO}_{4}{ }^{2-} と \mathrm{WO}_{4}{ }^{2-}$ を含む場合には, ワレ日上にピット が諗められる.

(6) アニオンの酸化批 $\mathrm{CrO}_{4}{ }^{2-}>\mathrm{NO}_{3}{ }^{-}>\mathrm{H}_{2} \mathrm{PO}_{2}{ }^{-}$である から， $\mathrm{Cl}^{-}$存在下で生ずるピットおよびワレの抑制力と酸 化力とは関係がないと考えられる。

終りに，本実験を遂行するに当り衙指尊いただいた名古 屋工業大学金属工学科大谷南海男教授，ならびに実験結果 について御討論いたたいた東京大学工学部冶金学科久松敬 弘教授と研究室の力↔に深く感謝いたします。 